\title{
THE STUDY OF SOCIOLOGY IN INSTITUTIONS OF LEARNING IN THE UNITED STATES. II.
}

Summing up the results on the present study of sociology, we find that 169 different men's colleges give some attention to sociology, while I 50 of these give the equivalent of one course or more in the subject. In the women's colleges, I 6 treat sociology. A total of 45 colleges and universities give fairly adequate treatment of the subject, offering three or more different courses covering various subdivisions of the sociological field. There is, however, no university in the United States in which the whole field of sociology is adequately covered. The nearest approach to such treatment is at the University of Chicago, Yale University, and Columbia University. Besides the institutions mentioned above, sociology is gradually making its way into technological institutions, normal schools, and theological institutions. The growth of such study in normal schools is most marked, while theological institutions are not making as rapid progress as seemed probable a few years ago. The technical colleges are just awakening to the advisability of treating a subject apparently so remote from a purely technical curriculum.

Our only basis of comparison, in determining the growth of sociological study, is Mr. Folkmar's report of I894. He found " 29 colleges having regular courses in sociology, using the term in the looser sense to include charities and corrections, while 24 have sociology proper, defining the term as the study of society. These figures do not include the institutions that give instruction in charities and correction, or the science of society, incidentally to ethics, economics, etc. Of this sort there are 6 more in sociology, and 20 in charities and correction, some of which give quite extended instruction in these subjects. Five of the 8 women's colleges reporting give courses in sociology, some of them being well equipped, while 4 have courses in charities and correction. Eleven colleges give the number of students, which ranges from 8 to 250 in each course, or an average of 50 . The 
number of students in courses in charities and correction ranges from 8 to I I9, with an average of 43."

The growth shown by a comparison of these figures is so evident that no comment is necessary. Since 1890 the field of sociology has differentiated, until the division into sociology proper, and charities and corrections, has no longer any significance. Consequences of this differentiation are that the classes are notably smaller; that dilettanteism and superficiality in sociological study are beginning to be things of the past; that a single course in the study is seen to be inadequate to cover the sociological field; and that a postgraduate school of sociology is coming to be recognized as the only adequate institution for such study.

While the growth of sociology is obvious, it would be idle to deny that certain tendencies are at work which tend to challenge its right to an important position in the field of the sciences, or in educational institutions. The action of certain of our most important universities, as noticed in the first part of this paper, is evidence enough of this movement. The arguments of such critics may, perhaps, be stated somewhat as follows : Sociology must define itself either as a body of doctrine, as a point of view, or as a method of research. It has tried to define itself as a body of doctrine, and it has failed in the attempt. If it is merely a point of view, it cannot be separated from the matter in discussion and must subordinate itself to the various social sciences. It has as yet made no serious attempt to develop itself as a method of research, and must develop itself on these lines and show its fruitfulness before it can demand consideration at the bar of science. It is no part of the business of this paper to answer these charges theoretically. If an examination of the classified list of sociological courses shows them to be well founded, then there is nothing to say, unless, indeed, it be to advise the sociologist to develop sociology as a method of research as rapidly as possible. My purpose in calling attention to this tendency is merely to give a true representation of the present status of sociology in the academic world. No treatment of this subject would be complete which minimized this attitude. 
It seems evident, then, that the position of sociology in education is in dispute. In this connection a few of the answers to the question as to the position of sociology in general education may be of interest :

I do not believe that sociology is at present far enough advanced to warrant much specialization apart for the actual workings of social institutions, and such general courses as enable the student to appreciate current problems as he comes upon them.

Seems to the writer too vast a field for a mere course in college. Should be a postgraduate course, with little else in it.

Has not yet attained sufficient definiteness as a "body of doctrine" to be insisted upon as part of a general education. But every teacher should appreciate the sociological point of view.

A better knowledge of what it is will create a demand equal with political economy.

There is a growing demand to know the civilization in which one has to live. Perhaps no branch has a higher importance.

We find deep interest in it, and believe it should be put in curriculum for B.L., B.Ph., and B.A. Let student select it as alternate to any one of several studies, as higher mathematics, Greek, philosophy, etc.

I think an elementary study of the subject almost indispensable to right understanding of a number of other subjects.

Sociology organizes and furnishes point of view for all human sciences.

A general survey is well-nigh essential.

It seems to me it should be applied rather than theoretical, and has the utmost importance - nothing is more important.

Because of the paramount importance of the social life, I would cut down the studies of the classics, and of physical science if necessary, in order to make room for it.

The study of sociology is invaluable. Demand is general and urgent. No subject is of greater importance.

Sociology has the importance Plato and Aristotle gave it. It connects other studies with life.

We note an imperative and increasing demand for teaching of sociology.

The following table is an attempt at a classification of the various sociological courses offered by colleges and universities. It is designed to indicate the relative development and comparative importance of the various divisions of the sociological field, as well as to show the comparative amount of attention given to each of these subjects in the academic world. It is hoped that it may also serve as an index to the first part of the larger descriptive catalogue to follow. This descriptive catalogue will consist of all the announcements and descriptions of courses in sociology that it has been possible to collect. They will be 
arranged in the usual way under the heads of (I) colleges for men and coeducational institutions, (2) colleges for women, (3) schools of technology, (4) divinity schools, and (5) normal schools. Of these various classes, the last two do not pretend to anything like completeness. It is hoped, however, that enough is given to be representative of the best treatment of sociology in these institutions.

\section{CLASSIFIED LIST OF COURSES IN SOCIOLOGY, I901.}

I. SOCIAL GEOGRAPHY.

Ia. Physico-Social; the Environment. Physical basis of industrial organization Economic antecedents of society
Yale University, Conn.

- University of Michigan.

- Bryn Mawr College, Pa.

\section{Ib. Racial Demography.}

(See also under II, “Social Statistics.")

$\begin{array}{llllll}\text { Bio-geography - } & - & - & - & - & \text { Lombard College, Ill. } \\ \text { Anthropological geography } & - & - & - & - & \text { Dartmouth College, N. H. } \\ \text { Racial demography - } & - & - & - & - & \text { Columbia University, N. Y. } \\ \text { Race traits and distribution } & - & - & - & - & \text { University of Pennsylvania. } \\ \text { Demography, dispersion of races } & - & - & - & \text { Brown University, R. I. }\end{array}$

Incidental treatment in Willamette University, Ore.

II. SOCIAL STATISTICS AND DEMOGRAPHY.

(See also I $b$, "Racial Demography.")

\begin{tabular}{|c|c|c|c|c|}
\hline Statistics and sociology & 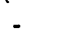 & - & - & \\
\hline Elementary statistics & - & - & - & \\
\hline \multicolumn{5}{|c|}{ Statistical study of the evolution of man - } \\
\hline \multicolumn{4}{|c|}{ Special topics in social economics - } & \\
\hline Comparative statistics & - & - & - & \\
\hline Moral and culture statis & tics & - & - & \\
\hline Social statistics & - & - & - & \\
\hline Social statistics & - & - & - & \\
\hline \multicolumn{4}{|c|}{ Theory and practice of statistics } & \\
\hline Social statistics - & $\cdot$ & - & - & \\
\hline Elementary statistics & - & - & - & - \\
\hline Advanced statistics & - & - & - & - \\
\hline Statistics and sociology & - & - & - & - \\
\hline Theory of statistics & - & - & - & - \\
\hline Laboratory work in stat & istics & & - & - \\
\hline Statistics, economic and & soci & $\log$ & & - \\
\hline Sociology and statistics & - & - & - & - \\
\hline Social statistics - & - & - & - & 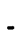 \\
\hline Government statistics & - & - & - & - \\
\hline Social statistics - & - & - & - & - \\
\hline Laboratory work & - & - & - & - \\
\hline
\end{tabular}

Leland Stanford University, Calif.

Yale University, Conn.

“

Catholic University of Am., D. C.

Columbia University, D. C.

University of Chicago, Ill.

State University of Iowa.

University of Kansas.

University of Michigan.

Dartmouth College, N. H.

Cornell University, N. Y. “

Columbia University, N. Y.

“

“

Western Reserve University, $\mathrm{O}$.

Ohio State University.

Brown University, R. I.

University of Wisconsin.

“ 
Incidental treatment in University of Indiana; Iowa College; Western College, Ia.; Harvard University, Mass.; University of Nebraska; Syracuse University, N. Y.; University of Wooster, O.; University of Oregon ; University of Pennsylvania ; Wells College, Mass.

II a. Problems of Population, Race Problem, etc.

Race problem

Race problem in the United States

Social problem in the South

Race problem

Negro and Indian problem
Leland Stanford University, Calif. Atlanta University, Ga. “6

Roger Williams University, Tenn. Hampden-Sidney College, Va.

\section{IIb. Sociology of Colonization.}

Colonization, economic and social - _ _ - Yale University, Conn.

Social conditions of the United States island populations - - - - - - S State University of Iowa.

Seminary on colonies and colonization - - University of Nebraska.

III. SOCIOLOGY OF THE DOMESTIC GROUP.

$\begin{array}{llllll}\text { Sociology of the family - } & - & - & - & - & \text { Leland Stanford Univ., Calif. } \\ \text { Self-perpetuation of society } & - & - & - & - & \text { Yale University, Conn. } \\ \text { Sex in social organization } & - & - & - & - & \text { University of Chicago, Ill. } \\ \text { The family - - - } & - & - & - & - & \text { “ } \\ \text { Reproductive association } & - & - & - & - & \text { Lombard University, Ill. }\end{array}$

Incidental treatment in University of Colorado; Trinity College, Wesleyan University, Conn.; Carthage College, Northwestern University, Ill.; Butler College, Ind.; Baker University, Kan.; Bates College, Me.; Woodstock College, Md.; Harvard University, Clark University, Mass.; University of Michigan; University of Minnesota; University of the State of Missouri; Alfred University, Cornell University; Columbia University, Union University, Syracuse University, N. Y.; University of North Dakota; Oberlin College, University of Wooster, O.; Williamette University, Ore.; University of Pennsylvania, Swarthmore College, Pa.; Brown University, R. I.; Rockford College, Ill.; Woman's College of Baltimore, Md.; Wellesley College, Wells College, Mass.

\section{SOCIOLOGY OF THE MUNICIPAL GROUP.}

Municipal politics Municipal economy American cities Urban communities Municipal sociology Applied sociology .

History of English cities and towns Municipal government Seminary on cities City and its problems
Yale University, Conn. Columbian University, D. C. University of Chicago, Ill. c6

“

State University of Iowa. Tufts College, Mass. Williams College, Mass. University of Nebraska. Heidelberg College, $\mathrm{O}$.

Incidental treatment in University of California ; University of Colorado, University of Denver, Col.; Wesleyan University, Conn.; Delaware College; Carthage College, Northwestern University, Ill.; University of Indiana, Butler College, Ind.; 
Western College, Ia.; Johns Hopkins University, Md.; University of Michigan; University of the State of Missouri ; Alfred University, Cornell University, Union University, N. Y.; Oberlin College, University of Wooster, O.; Willamette University, Ore.; University of Pennsylvania, Swarthmore College, $\mathrm{Pa}$; Vanderbilt University, Tenn.; University of Washington; University of Wisconsin; Wells College, Mass.

V. SOCIOLOGY OF THE RURAL GROUP.

Rural communities - - - - - - University of Chicago, Ill.

Incidental treatment in Trinity College, Conn.; University of Illinois; Iowa College ; University of Michigan ; Columbia University, N. Y.; University of Wooster, O.; University of Wisconsin.

VI. SOCIOLOGY OF THE NATIONAL GROUP.

VIa. General Descriptive Treatment.

Sociological conception of state and government

Contemporary society in the United States -

Structure of English society - - - .

Primitive social control - - - - -

American social life - - - - - - Iowa College.

English social life _ - _ _ _ _ - $\quad$ - Tufts College, Mass.

Jewish social life - $\quad$ - $\quad$ - $\quad$ - _ - - Alma College, Mich.

Democracy in the United States - - - - Vanderbilt University, Tenn.

Modern state and its social function - - Wilson College, O.

VIb. Sphere of State Activity; the State and Industry; Socialism.

Note.-Only those treatments of socialism are included in this schedule in which the point of view seems to be predominantly social, not economic.

Industrial policy - - - - - -

Anarchism, socialism, and communism - -

Individualism, socialism, and practical social problems

American experience with state control - Sociology - - $\quad$ - $\quad$ - $\quad$ - $\quad$ - $\quad$ Socialism and communism $\quad-\quad$ - $\quad$ Socialism, history and philosophy - - Socialism Modern socialism - $\quad$ - $\quad$ Socialism and social reform - $-{ }_{-}$ Private property rights - - - $_{-} \quad$ Socialistic movements - $\quad$ - $\quad$ - $\quad$ Socialism and social reform - $\quad-\quad-$ History and theory of socialism - - -

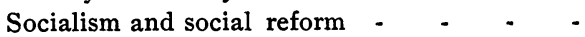
Socialism - - - - - - -

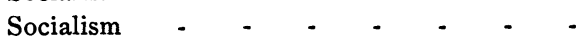
Socialism - - - - - - -
Yale University, Conn. c6

Columbian University, D. C. University of Chicago, Ill. Wheaton College, Ill. University of Indiana. DePauw University, Ind. Butler College, Ind. Boston University, Mass. “

Princeton University, N. J. Manhattan College, N. Y. Syracuse University, N. Y. Ohio State University. Oberlin College, $\mathrm{O}$. Otterbein University, $\mathrm{O}$. Swarthmore College, $\mathrm{Pa}$. Brown University, R. I. Washington and Lee Univ., Va. 
Socialism and social reform

Communistic and socialistic theories

Economic functions of the state
Smith College, Mass.

Barnard College, N. Y.

University of Rochester, N. Y.

Incidental treatment in Leland Stanford University, Calif.; University of Colorado; John B. Stetson University, Fla.; Wabash College, DePauw University, Hanover College, Ind.; Coe College, Ia.; Baker University, Kan.; Johns Hopkins University, Md.; Harvard University, Mass.; University of Minnesota; University of the State of Missouri ; Unıversity of Nebraska ; Dartmouth College, N. H.; Princeton University, N. J.; Adelphi College, Syracuse University, N. Y.; Trinity College, Conn.; University, of North Dakota; University of Cincinnati, O.; Wesleyan University; University of Oregon; University of Pennsylvania ; Lehigh University, Pa.; Southwestern University, Tex.; Brigham Young College, Utah; University of Wisconsin ; Woman's College of Baltimore, Md.; Wellesley College, Mass.

VIc. Social Legislation.

Social legislation - - - - - - - - $\quad$ - Leland Stanford University, Calif.

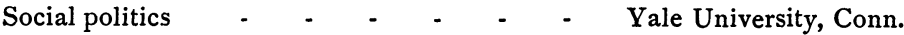

Socialism and contemporary social legislation - State University of Iowa.

Economic legislation - - - - - West Virginia University.

Incidental treatment in the University of Pennsylvania and the University of Wisconsin.

\section{VId. Democracy, Social Philosophy of.}

Modern democratic movement in United States and England - - - - - -

Modern democratic movement in France and Germany

Progress and democracy - - - -

Democracy in the United States - - - Vanderbilt University, Tenn.

For colonization see II $b$ above.

VII. SOCIOLOGY OF THE DEPENDENT CLASSES ; CHARITIES.

\begin{tabular}{|c|c|c|c|c|}
\hline Charities & - & - & - & Leland Stanford University, Calif. \\
\hline Causes of poverty - & $\cdot$ & - & - & “ \\
\hline Charities and crime & - & - & - & Colorado College \\
\hline Social therapeutics & - & - & - & Columbian University, D. C. \\
\hline Problems of pauperism & and crime & - & - & University of Illinois. \\
\hline Contemporary charities & - & $\cdot$ & - & University of Chicago, Ill. \\
\hline Philanthropy in its histo & rical devel & pmen & it & “ \\
\hline Abnormal variations of & the associ & tive & rocess & Lombard University, Ill. \\
\hline Social pathology & - & - & - & University of Indiana. \\
\hline Defectives, dependents, & and delin & uents & - & DePauw University, Ind. \\
\hline Organized philanthropy & - & - & - & Butler College, Ind. \\
\hline Charities and correctior & as & $\cdot$ & - & Coe College, Ia. \\
\hline Charities and penology & - & - & - & Iowa College. \\
\hline American and Europea & rities & - & - & University of Kansas. \\
\hline Social pathology - & - & - & - & \\
\hline
\end{tabular}


Public aid, charities, and corrections

Social pathology - - - -

American charities - -

Pauperism and charities - $\quad-\quad-$

Charities - - - - - - - $\quad$ -

Modern philanthropy - $\quad$ - $\quad$ - $\quad$ -

Pauperism, poor laws, and charities - -

Degenerate social classes - $\quad$ - $\quad$ -

Dependent and defective classes - $\quad$ -

Sociology (charities and philanthropy) - -

Social debtor class - $\quad$ - $\quad$ - $\quad$ - $\quad$ -

Charities and reform - $\quad-\quad-\quad-\quad$ -

Charities and corrections - - - -

Social problems and conditions - - -

Contemporary charities - - - - -

Charities and corrections - - -

Public and private charities - $-{ }_{-}-{ }_{-}$

Charities organization - $\quad-\quad$ - $\quad$ -

Problems of poverty and crime - - -

Economics and charities - $\quad-\quad$ -

Social pathology - $\quad$ - $\quad$ - $\quad$ - $\quad$ - $\quad$ -

Some problems of poverty - - - - - $\quad$ Smith College, Mass.

Dependent and delinquent classes - - - - Wellesley College, Mass.

Charities and corrections - - - - - Vassar College, N. Y.

Social economics (defective, dependent, and delinquent classes) - - - -
Johns Hopkins University, Md.

University of Minnesota.

University of State of Missouri.

William Jewell College, Mo.

University of Nebraska.

Cornell University, N. Y.

Columbia University, N. Y.

Syracuse University, N. Y.

University of Cincinnati, $\mathrm{O}$.

Ohio State University.

University of Oregon.

Bucknell College, Pa.

University of Pennsylvania.

Brown University, R. I.

West Virginia University.

University of Wisconsin.

$$
\text { “ }
$$

Rockford College, Ill.

Woman's College of Baltimore, Md.

“6

Converse College, O.

Incidental treatment in University of Colorado ; Trinity College, Wesleyan University, Yale University Conn.; Carthage College, Northwestern University, Ill.; Cornell College, Tabor College, Ia.; Baker University, Kan.; Bates College, Colby College, Me.; University of Michigan; Nebraska Wesleyan Unıversity; Dartmouth College, N. H.; Union University, N. Y.; University of Wooster, O.; Pacific University, Ore.; Swarthmore College, Pa.; Southwestern University, Tex.; Wells College, Mass.

VIII. SOCIOLOGY OF THE DELINQUENT CLASSES; CRIMINOLOGY.

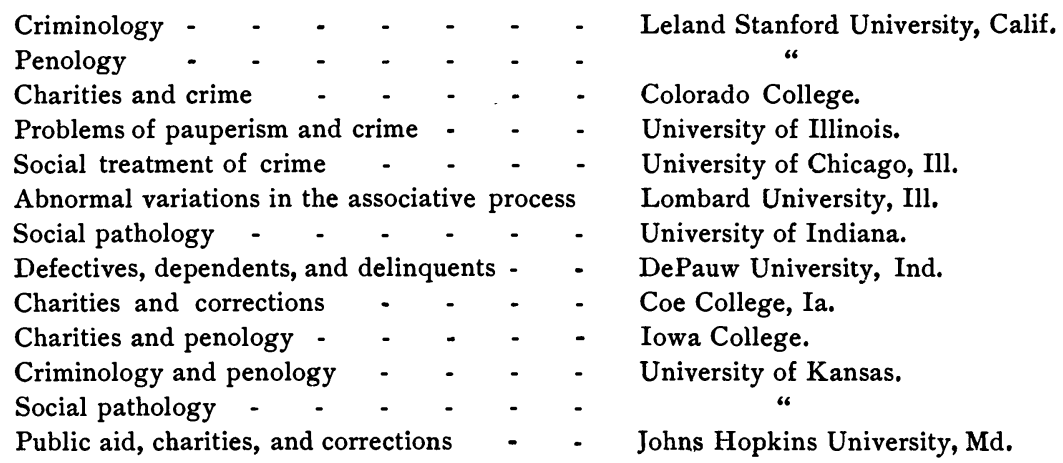




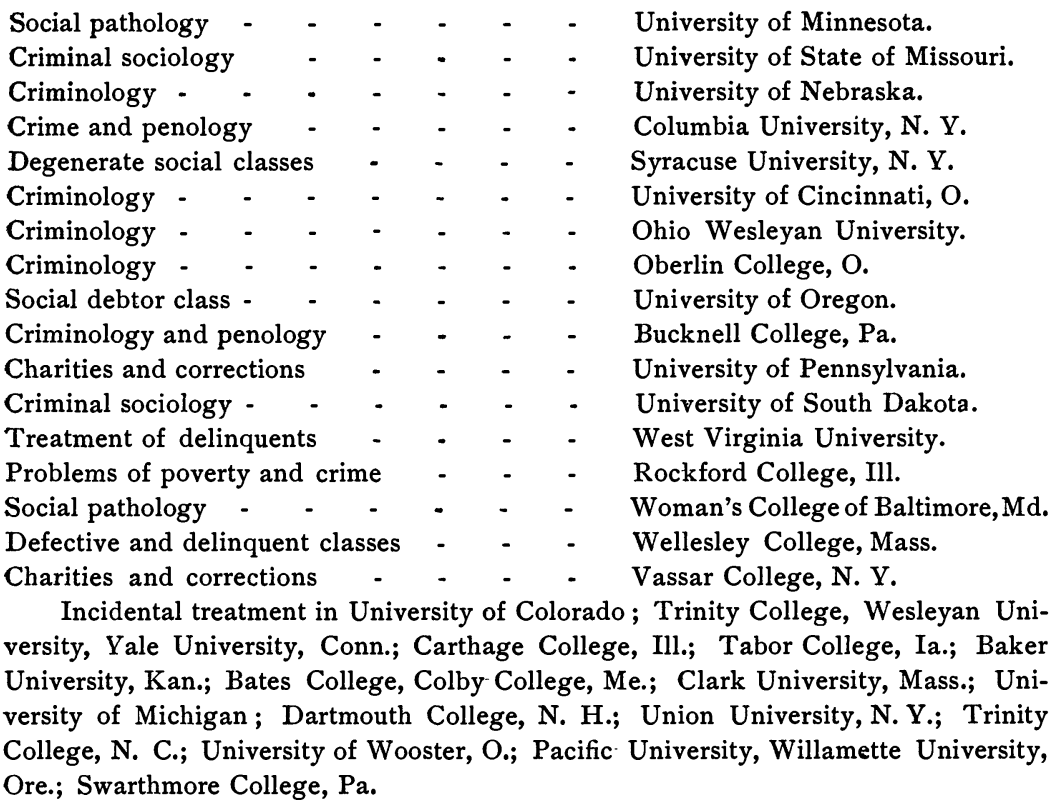

IX. SOCIOLOGY OF THE INDUSTRIAL GROUP ; SOCIAL ECONOMICS.

(See also under VI.)

Economic condition of laborers
Introduction to economics

Labor question in Europe and the United States

Economics

Problems of labor and capital - - -

Application of economic theory to social prob-
University of California.

“6

Pomona College, Calif.

Leland Stanford University, Calif.

Trinity College, Conn.

Wesleyan University, Conn.

“

Yale University, Conn.

“

66

66

66

Catholic Univ. of America, D. C.

Catholic Univ. of America, D. C.

University of Illinois.

University of Chicago, Ill.

“6

66

Northwestern University, Ill.

Wabash College, Ill.

Butler College, Ind.

Simpson College, Ia. 
Industrial history and problems of labor Industrial revolution in its social aspects Development of modern industry - Social history of the United States . Labor problems

Social aspects of the labor question Labor question

Problems of industrial organization Problems in political economy Social and industrial reform Genesis of the industrial order Development of industrialism Private property rights - Practical economics Elementary social economics The modern régime Problems of modern industry Special economic topics Socialism and social reform Remedial measures History of industrial society Practical problems .

Economic problems Economic problems Social economics Elements of economics Social economics Industrial problems The industrial era Industrial problems Practical economic problems . Economic problems Economics and charities Social and economic condition of workingmen Social economics Modern labor problem - - - - Labor problem - - - - - -

\author{
Iowa College.
}

State University of Iowa.

Bowdoin College, Me.

“

Johns Hopkins University, Md.

Boston University, Mass.

Harvard University, Mass.

“

University of Michigan.

“

Princeton University, N. J. “

“

Adelphi College, N. Y. Cornell University, N. Y. “6

Columbia University, N. Y. University of Rochester, N. Y. Syracuse University, N. Y. University of Cincinnati, $\mathrm{O}$. Ohio State University.

“

University of Oregon. Haverford College, $\mathrm{Pa}$. Central High School, Pa. Swarthmore College, Pa. U. S. Grant University, Tenn. University of Utah. University of Vermont. University of Washington. West Virginia University, University of Wisconsin. Woman's College of Baltimore, Md. Radcliffe College, Mass. Wellesley College, Mass. 66

Vassar College, N. Y. Oxford College, O.

Incidental treatment in University of Arizona ; University of Southern California ; University of Denver, Col.; Delaware College, Gallaudet College, Georgetown University, D. C.; John B. Stetson University, Fla.; University of Indiana ; Coe College, Western College, Ia.; University of Kansas; Bates College, Colby College, Me.; Williams College, Mass.; Hope College, Mich.; University of Mississippi ; William Jewell College, Mo.; University of Nebraska ; Dartmouth College, N. H.; St. Lawrence University, New York University, University of Rochester, N. Y.; Davidson College, Trinity College, N. C.; University of North Dakota ; University of Wooster, Antioch College, O.; Willamette University, Ore.; Dickinson College, University of Penn- 
sylvania, Lehigh University, Pa.; Erskine College, S. C.; University of Tennessee, Vanderbilt University, Tenn.; Southwestern University, Tex.; Milton College, Wis.

X. SOCIAL REFORM. PRACTICAL SOCIOLOGY; SOCIAL PROBLEMS.

Modern social and sociological problems

Practical economic and social problems

Social science

Practical sociology

American social conditions

Study of sociological problems

Sociology

Methods of social amelioration

Practical problems - - -

Social questions - - $\quad$ -

Practical sociology -

Questions of the day

Sociology

Sociology

Social reform (half-term)

Applied sociology

Sociology

Social problems

Sociology

Social history of the United States -

Social science - $\quad-\quad-\quad-$

Sociology - - - - - -

Methods of social reform

Socialism and social reform

Practical sociology

Social and industrial reforms

Problems of sociology

Introduction to the study of sociology

General sociology -

Sociology

Sociology

Sociology

The modern régim

Theories of social reform

Practical sociology -

Current questions -

Practical sociology

Remedial measures

Introduction to sociology

Practical sociology

Socialism and social reform

Introduction to sociology

Economic problems

Sociology
Colorado College.

Trinity College, Conn.

Wesleyan University, Conn.

Yale University, Conn.

"6

Illinois Wesleyan University.

Carthage College, Ill.

University of Chicago, Ill.

Northwestern University, Ill.

University of Indiana.

DePauw University, Ind.

Hanover College, Ind.

Drake University, Ia.

Parsons College, Ia.

Iowa College, Ia.

State University of Iowa.

Tabor College, Iowa.

Kansas City University, Mo.

Berea College, $\mathrm{Ky}$.

Bowdoin College, Me.

Bates College, Me.

Colby College, Me.

Boston University, Mass. “

Tufts College, Mass.

University of Michigan.

66

Hillsdale College, Mich.

Hamline University, Minn.

Alfred University, N. Y.

Adelphi College, N. Y.

Saint Lawrence University, N. Y.

Cornell University, N. Y.

Columbia University, N. Y.

Syracuse University, N. Y.

University of North Carolina.

Trinity College, N. C.

University of Cincinnati, $\mathrm{O}$.

Hiram College, $\mathrm{O}$.

Oberlin College, $\mathrm{O}$.

66

Pacific University, Ore.

Haverford College, Pa.

Allegheny College, $\mathrm{Pa}$. 
Social reform in the nineteenth century -

Practical sociology

Elements of sociology

Methods of social reform

Social movements in the nineteenth century

Seminar in social problems

Sociology and social problems

Social problem

Some sociological problems

Socialism and social reform

Sociology

Theories of social reform

Elements of sociology
University of Pennsylvania.

Susquehanna University, Pa.

Swarthmore College, $\mathrm{Pa}$.

West Virginia University.

66

Lawrence University, Wis.

Beloit College, Wis.

University of Wyoming.

Smith College, Mass.

Wells College, Mass.

Barnard College, N. Y.

Randolph-Macon Wom. Col., Va.

Incidental treatment in Blackburn University, Ill.; Cornell College, Western College, Ia.; Midland College, University of Kansas, Kan.; University of Wooster, O.; Willamette University, Ore.; Roger Williams University, Tenn.; Southwestern University, Tex.; Converse College, $\mathrm{O}$.

\section{GENETIC SOCIOLOGY; COMPARATIVE SOCIOLOGY.}

(Note.-A genetic treatment of any special subject is put under that subject.)

Sociology

Evolution of society

Evolution of society

Development of society

Social history

Evolution of society (seminar)

Theory of evolution

Social evolution

Sociology

Introduction to sociology

Principles of sociology -

Sociology

Social institutions

Social science

Social institutions

Theoretical sociology
Pomona College, Calif.

University of Colorado.

Iowa College.

Missouri Valley College, Mo.

Adelphi College, N. Y.

Cornell University, N. Y.

“6

Columbia University, N. Y.

Manhattan College, N. Y.

New York University.

Union University, N. Y.

Brown University, R. I.

Baylor University, Tex.

University of Vermont.

Bryn Mawr College, Pa.

$\mathrm{XI}$. Animal and Primitive Human Society; Anthropo-Sociology.

Science of society

Social origins

Comparative study of association

Development of association

Anthropology

Ethnology

Race psychology

Race psychology

Sociology in the light of anthropology

Primitive society
Yale University, Conn.

University of Chicago, Ill.

Lombard University, Ill.

“

Butler College, Ind.

Clark University, Mass.

University of the State of Missouri.

University of Nebraska.

Western Reserve University, $O$.

Ohio State University. 
Anthropology in relation to social science

Sociology

Sociology

American primitive society -
University of Oregon.

Dickinson College, Pa.

University of Pennsylvania.

Bryn Mawr College, $\mathrm{Pa}$.

Incidental treatment in Trinity College, Wesleyan University, Conn.; University of Illinois, Northwestern University, Ill.; University of Indiana; University of Kansas; University of Michigan; University of Minnesota; Syracuse University, N. Y.; University of North Dakota ; Oberlin College, O.; Willamette University, Ore.; West Virginia University.

\section{XIb. Development of Society in Historic Times; Social History.}

Social history of Greece

Economic and social history of the English colonies in America - - - - -

(Social history of) France under the Bourbons Homeric society

Sociological aspects of mediæval guilds - -

Development of association, continued -

Social history - - - - - - -

Sociological interpretation of history - -

English social history - - - - -

Growth and development of social thought and institutions $\quad-\quad \cdot \quad-\quad$.

Historic sociology - $\quad-\quad-\quad-\quad-\quad-$

Social history of England - - - - -

Development of English civilization - Oriental social life - $\quad-\quad-\quad-\quad-\quad$ -

University of California.

16

6

Yale University, Conn.

Catholic Univ. of America, D. C.

Lombard University, Ill.

Butler College, Ind.

Washburn College, Kan.

Manhattan College, N. Y.

Ohio State University.

Central High School, Pa.

University of Pennsylvania.

“6

66

Wells College, Mass.

Incidental treatment in University of Southern California; University of Chicago, Ill.; University of Michigan; Saint Lawrence University, University of Rochester, N. Y.; University of North Dakota ; University of Cincinnati, O.; University of Oregon; Central Pennsylvania College ; University of Wisconsin.

\section{SOCIAL PSYCHOLOGY.}

(See also under XX below, "General Sociology.")

\begin{tabular}{|c|c|c|c|c|}
\hline \multicolumn{3}{|c|}{ Psychology in relation to sociology } & - & University of Denver, Col. \\
\hline The mental reactions & - & 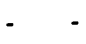 & & Yale University, Conn. \\
\hline Public opinion & - & . & - & University of Chicago, Ill. \\
\hline Problems of social dyna & mics, sem & & - & “ \\
\hline Development of mind $i$ & the race & - & & “ \\
\hline Primitive social control & - & - & & “ \\
\hline Origin and psychology & of the occ & pations & & “ \\
\hline Social psychology - & - & - & - & Northwestern University, Ill. \\
\hline Social psychology - & - & - & 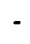 & University of Indiana. \\
\hline Socialization and socia & control & - & - & University of Kansas. \\
\hline Psychological sociolog. & - & - & - & University of Michigan. \\
\hline Social psychology - & - & - & - & University of the State of Missou \\
\hline Social psychology - & - & - & - & University of Nebraska. \\
\hline
\end{tabular}


Psychology of society - - - - - - - - $\quad$ University of Nebraska.

Social psychology - - - - - - Cornell University, N. Y.

Seminar in sociology (the social mind) - - Columbia University, N. Y.

Social psychology - - _ _ - _ _ - Western Reserve University, O.

Sociology - - - - - - - - Dickinson College, Pa.

The psychological sociologist - - - University of Wisconsin.

Incidental treatment in University of Colorado ; Butler College, Ind.; Iowa College, Tabor College, Ia.; Tufts College, Clark University, Mass.; Dartmouth College, N. H.; Princeton University, N. J.; Syracuse University, N. Y.; Ohio Wesleyan University; Ursinus College, University of Pennsylvania, Swarthmore College, Pa.; Brown University, R. I.; University of Utah.

\section{SOCIAL ETHICS.}

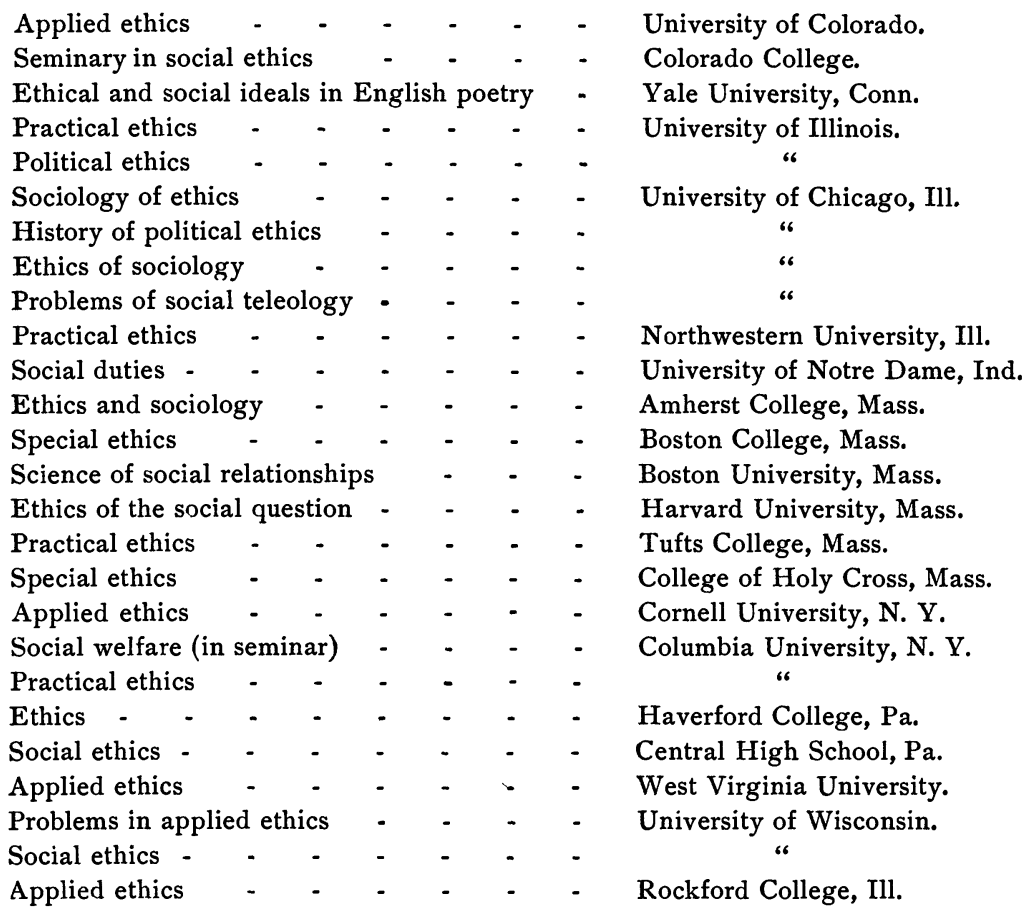

Incidental treatment in University of California, Leland Stanford University, Calif.; University of Denver, Col.; Gallaudet College, Georgetown University, D. C.; Rollins College, Fla.; St. Viateur's College, Carthage College, Ill.; Butler College, Ind.; Iowa College ; Campbell University, Kan.; Johns Hopkins University, Woodstock College, Md.; University of Michigan ; Carlton College, Minn.; University of Mississippi ; Dartmouth College, N. H.; Alfred University, Manhattan College, Union College, N. Y.; Trinity College, N. C.; Buchtel College, University of Cincinnati, Western Reserve University, Denison University, University of Wooster, O.; Moraivan College, Franklin and Marshall College, Allegheny College, Central Pennsyl- 
vania College, University of Pennsylvania, Pennsylvania State College, Villanova College, Pa.; Brown University, R. I.; Southwestern University, Tex.; Brigham Young College, Utah; University of Utah; University of Washington; Milton College, Wis.

XIV. SOCIAL PHILOSOPHY.

Theories of social progress
Social philosophy Sociology - - - - - - - -

Principles of sociology and theory of social forces - $\quad-\quad$ - $\quad-\quad-\quad-\quad$ -

Sociology - - - - - - -

Social philosophy - - - - - - -

Social theories

Elements of sociology

Elements of sociology

Social philosophy -

Sociology

Theories of social progress

Social philosophy

Sociology

Incidental treatment in Kansas City University; Colby College, Me.; Woodstock College, Md.; College of Holy Cross, Mašs.; University of the State of Missouri ;
University of California.

Yale University, Conn.

“

Wesleyan University, Conn.

Catholic Univ. of America, D. C.

University of Chicago, Ill.

$$
\begin{aligned}
& 66 \\
& 66 \\
& 66 \\
& 66
\end{aligned}
$$

Northwestern University, Ill.

Lombard University, Ill.

University of Indiana.

DePauw University, Ind.

University of Notre Dame, Ind.

State University of Iowa.

University of Kansas.

Bowdoin College, Me.

Boston University, Mass.

Harvard University, Mass.

University of Michigan.

University of Minnesota.

Dartmouth College, N. H.

Columbia University, N. Y.

Syracuse University, N. Y.

“6

Western Reserve University, O.

Ohio State University.

Ohio Wesleyan University.

University of Oregon.

University of Pennsylvania.

Brown University, R. I.

University of Vermont.

Washington and Lee Univ., Va.

West Virginia University.

University of Wyoming.

Woman's Coll. of Baltimore, Md.

Radcliffe College, Mass.

Wellesley College, Mass.

Wells College, Mass.

\footnotetext{
College, Md.; College of Holy Cross, Mass.; University of the State of Missouri ;
} 
Williams Jewell College, Mo.; University of Wooster, O.; Willamette University, Ore.; Susquehanna University, Pa.; U. S. Grant University, Tenn.

\section{XIVa. History of Social Theory.}

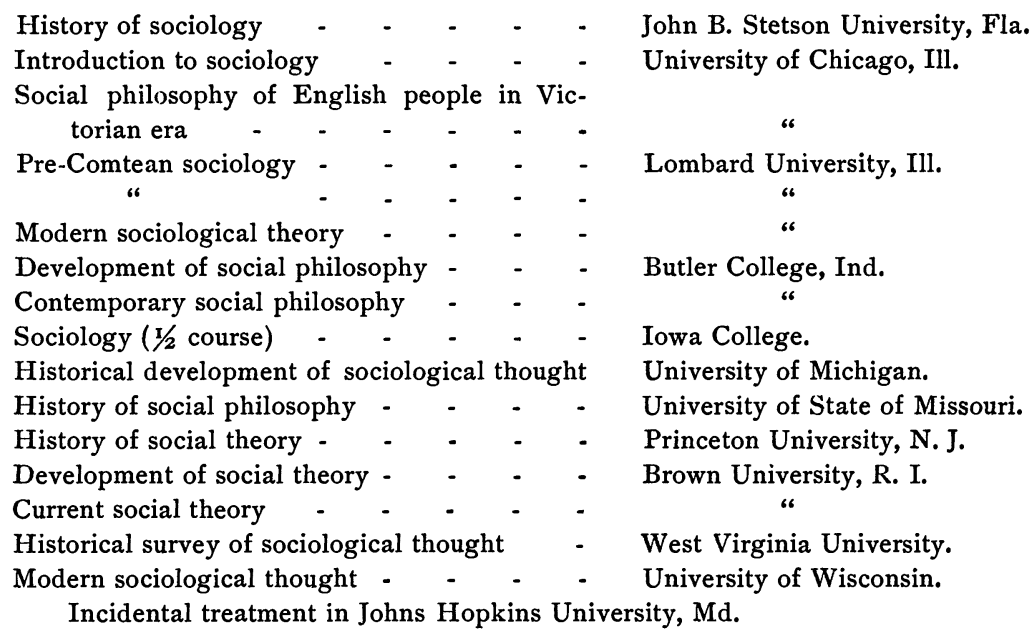

XV. METHODOLOGY AND CLASSIFICATION.

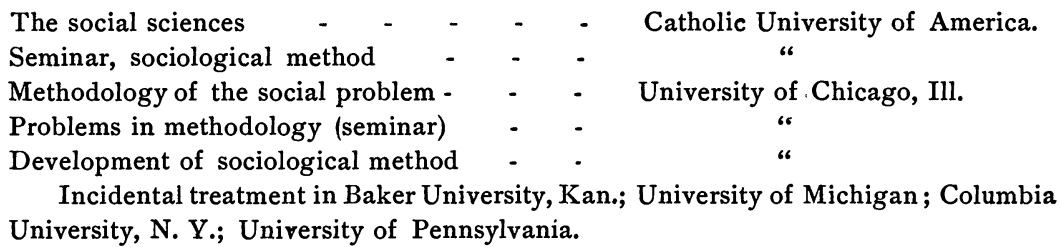

XVI. SOCIOLOGY OF RELIGION.

Psychology and pedagogy of religion Social teaching and influence of Christianity Social institutions of organized Christianity Sociology of religion Social mission of the church - - - Seminary; Christian doctrine of the social order Applied Christianity

The psychology of Jesus

Sociology of religion

Civil aspects of ecclesiastical organization

Christian sociology

Christian sociology

Christian ethics

Sociology from Christian point of view Christian sociology
Leland Stanford University, Calif. Yale University, Conn. University of Chicago, Ill. Lombard University, Ill. Boston University, Mass. Harvard University, Mass. Tufts College, Mass. Clark University, Mass. University of the State of Missouri. Columbia University, N. Y. Heidelberg University, $\mathrm{O}$. Franklin and Marshall College, Pa. “" Bucknell College, Pa. Vanderbilt University, Tenn. 
Christian sociology

Parochial organization and the institutional church

Social influences of Christianity - - -
University of the South, Tenn.

“

Wells College, Mass.

Wilson College, Pa.

Incidental treatment in University of California ; Butler College, Ind.; Iowa College ; College of the Holy Cross, Mass.; University of Michigan; Davidson College, N. C.; University of Wooster, O.; University of Pennsylvania, Swarthmore College, Villanova College, Pa.; University of Tennessee ; Southwestern University, Tex.; Milton College, Wis.

\section{SOCIOLOGY OF EDUCATION.}

Education and society - - - - - - - Leland Stanford University, Calif. Education as a social function - - - - University of Chicago, Ill. Principles of education - - - - - - Clark University, Mass. Social phases of education - - _ - - University of Michigan. Sociology in relation to education - - - - New York University. Social phases of education - - - - - Syracuse University, N. Y.

Incidental treatment in University of Arizona; University of Denver, Col.; Wesleyan University, Conn.; University of Illinois, Northwestern University, Ill.; Iowa College; University of Nebraska; Dartmouth College, N. H.; Alfred University, Cornell University, Columbia University, N. Y.; University of Oregon; University of Wooster, O.; University of Pennsylvania; Brown University, R. I.; Southwestern University, Tex.; University of Washington; Woman's College of Baltimore, Md.; Mount Holyoke College, Wellesley College, Mass.

\section{SOCIOLOGY OF ART AND AMUSEMENT.}

Art and the artist class - _ - _ _ _ - - University of Chicago, Ill.

Social forces in English romanticism - - - Butler College, Ind.

Social interpretation of art - _ _ - - Cornell University, N. Y.

Industrial and artistic evolution of society - Ohio State University.

Incidental treatment in Columbian University, D. C.; University of Michigan; University of Minnesota; Dartmouth College, N. H.; Trinity College, N. C.; University of Pennsylvania.

XIX. FIELD WORK.

Field work in connection with seminar on social amelioration

Field work in the study of social problems - Simpson College, Ia.

Laboratory work in statistics - - - - - Cornell University, N. Y.

Laboratory work in statistics - - - - Columbia University, N. Y.

Field work - $\quad$ - $\quad$ - $\quad-\quad$ - $\quad$ - $\quad$ - University of Wisconsin.

Field work - $\quad-\quad-\quad-\quad-_{-} \quad-\quad-\quad$ Barnard College, N. Y.

Incidental field work required in Leland Stanford University, Calif.; Wesleyan University, Conn.; Butler College, Ind.; Iowa College ; Tufts College, Mass ; Hamline University, Minn.; Union University, N. Y.; Swarthmore College, Pa.; Brown University, R. I.; West Virginia University.

XX. GENERAL SOCIOLOGY; DESCRIPTIVE SOCIOLOGY.

$\mathrm{XX} a$. General Elementary Courses.

Introduction to sociology - - - - - - Ouachita College, Ark.

Introduction to sociology - - - - Hendrix College, Ark. 


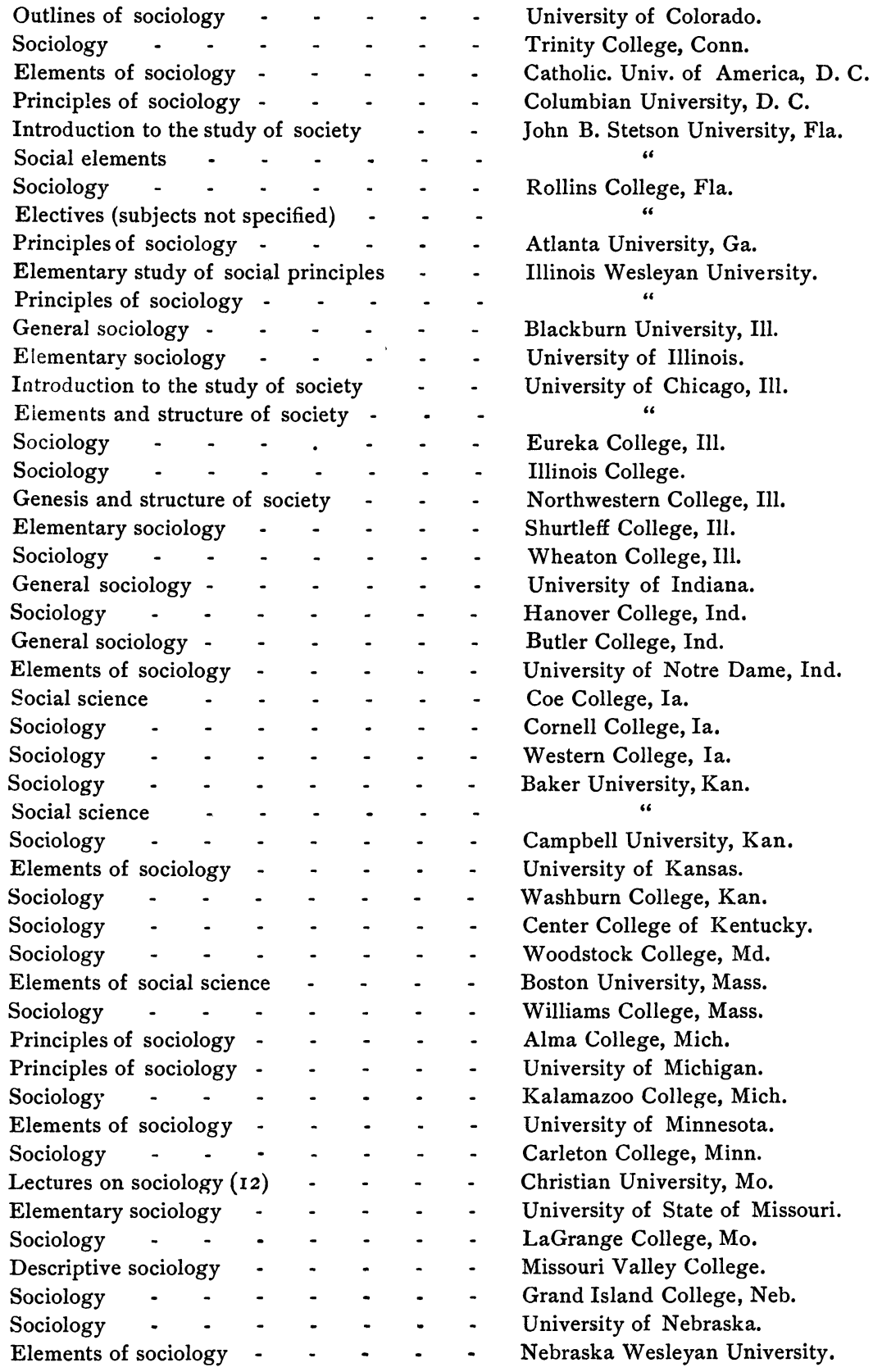




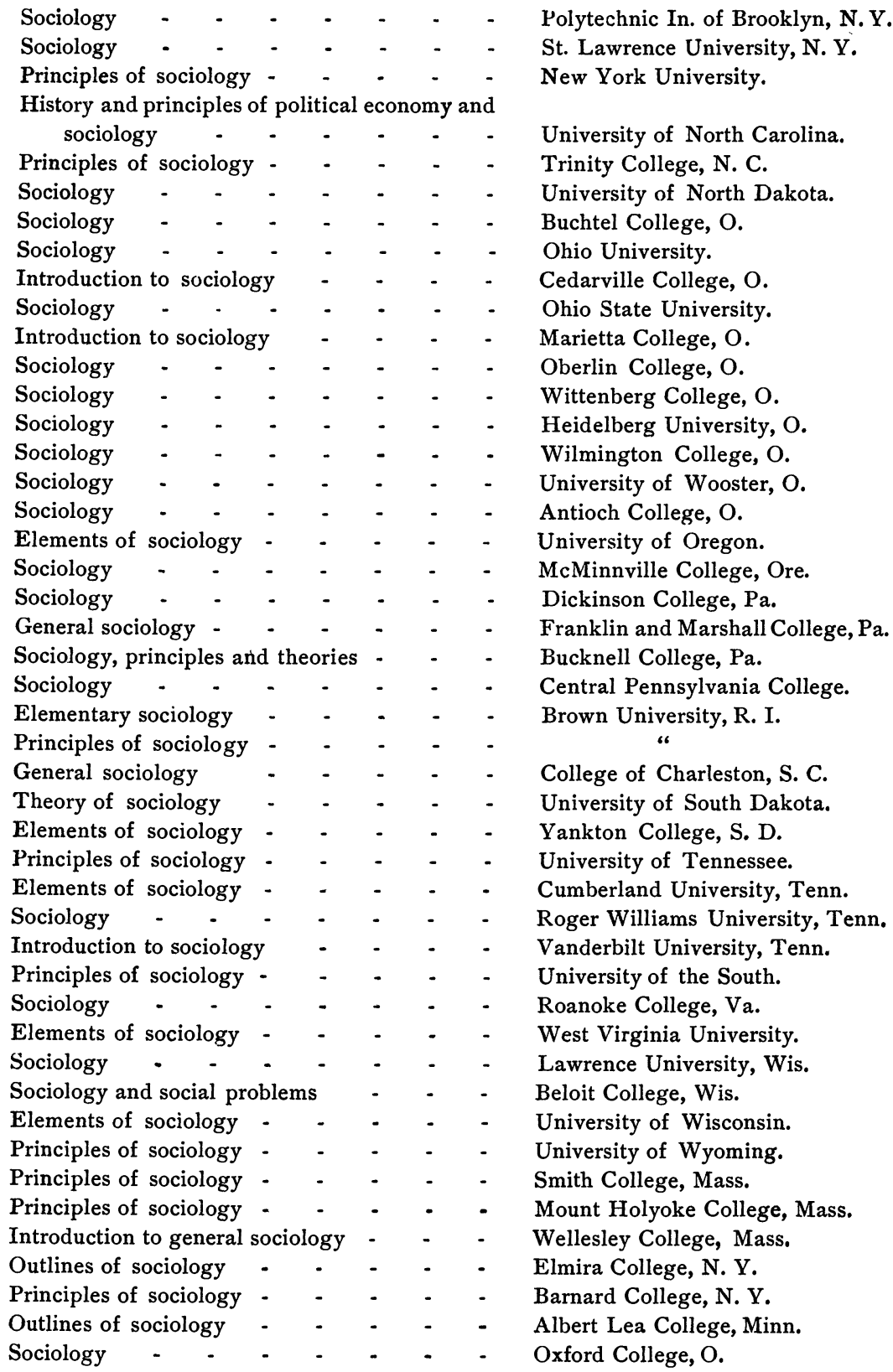




\section{$\mathrm{XX} b$. Advanced Courses in General Sociology.}

\section{The}

\section{Seminary}

Premises of general sociology

Outline of general sociology -

Seminary

Chief types of association - $-c^{-} \cdot$.

Seminar in general sociology - - - -

Seminar in economics and sociology - -

Special work with graduate students - -

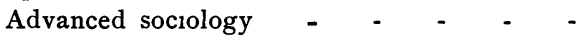

Seminary - - - - - - -

Research - - - - - - -

Advanced sociology, theoretical or practical .

Thesis work - - - - - - .

Seminary in sociology - $\quad \cdot \quad \cdot \quad$ -
Leland Stanford University, Calif. Wesleyan University, Conn. University of Chicago, Ill. 6

Northwestern University, Ill. Lombard University, Ill. University of Indiana. Tufts College, Mass. University of Michigan. University of the State of Missouri. 66

Syracuse University, N. Y. Ohio State University. 66

University of Wisconsin.

\section{CATALOGUE OF COURSES IN SOCIOLOGY.}

ARIZONAUNIVERSITY OF ARIZONA.

Sociology is taught incidentally in connection with the work in history, political science, and pedagogy. It is probable that courses in sociology will be offered as soon as the number of students demands it. Professor Adams.

\section{ARKANSAS- OUACHITA MALE AND FEMALE COLLEGE.}

No sociology taught until 190I, Nothing taught now except Small and Vincent's Introduction to the Study of Society. Three hours a week for five months. Twentyfive students. Professor Carter.

\section{HENDRIX COLLEGE.}

Just an introductory course of three months, three times a week. Professor Reynolds.

CALIFORNIA-

\section{UNIVERSITY OF CALIFORNIA.} HISTORY AND POLITICAL SCIENCE.

51. Introduction to economics. Assistant Professor Page and Mr. Hutchinson. A study of the elementary laws of economics as illustrated in the growth of industry and commerce; the influence of economic conditions on social and political development. Three hours, either half-year.

6I. Social and constitutional history of Greece. Dr. Ferguson. A consideration of the Greek intelligence as it is manifested in institutions, with special relation to its contributions to western civilization. Three hours, first half-year.

73. The United States under the constitution, I783-1850. Dr. Wakeman. With special emphasis on the constitutional and social development. Three hours, second half-year.

74. Local government and administration, with special reference to municipal problems. Assistant Professor Babcock. Three hours, first half-year.

75. Economic and social history of the English colonies in America, 1607-I776. Assistant Professor Page. Two hours, first half-year.

85. France under the Bourbons. Professor Bacon. A study of the social and 
political condition of France from the accession of Henry IV. to the fall of the monarchy. Two hours, second half-year.

88. Theories of social progress. Professor Moses. A critical examination of the theories hitherto offered to explain the forces, methods, and aims of social progress. Two hours, first half-year.

94. History of eastern Christendom. Professor Bacon. A critical study of the political, social, and religious institutions of the eastern Christian nations. Two hours, throughout the year.

98. Economic condition of laborers in England. Professor Moses. A historical and critical view of trade unions, economic legislation, and industrial progress, and their effects on the welfare of laborers. Two hours, first half-year.

\section{POMONA COLLEGE.}

ECONOMICS.

2. Sociology. The development of society, its functions, institutions, and forces at work. Forty-eight hours.

3. Economic and social history. A study of a few of the economic and social problems of the day, an attempt to trace their history, and a discussion of their treatment. Forty-eight hours.

\section{LELAND STANFORD JUNIOR UNIVERSITY.}

ECONOMICS AND SOCIOLOGY.

6. Socialism. Readings from the socialists and critical examinations of their proposals. Meaning and limits of the modern extension of the state activities. Two hours, second semester. Professor Aldrich.

8. Comparative condition of workingmen. Descriptive and statistical study of the social condition of workingmen in England, France, Germany, Australia, and more especially in the United States. Critical examination, in the light of experience and of economic theory, of the various attempts to improve the condition of workingmen. Workingmen's insurance and the trade-union movement in the United States receive special attention. Three hours, both semesters. Professor Aldrich.

14. The sociology of the family. The historical development and conditions of the modern family. Lectures, one required paper, and assigned reading. Two hours, first semester. Professor M. R. Smith.

I5. Race problems. A historical, sociological, and statistical study of the negro, Indian, and Chinese elements in the population. Lectures, assigned reading, and reports. Two hours, second semester. Professor M. R. Smith.

16. Statistics and sociology. Vital and social statistics, with special reference to method. Lectures, demonstrations, charting, and handling of statistics by students. Not open to first-year students. Two hours, second semester. Professor M. R. Smith.

I7. Causes of poverty. A study of abnormal conditions, the social causes and effects of degeneration, vice, and pauperism. Lectures, assigned reading, and reports. Open to students who have had nine hours' work in the department. (Alternate with Course 19.) Three hours, first semester. Professor M. R. Smith.

18. Charities. Supplementary to Course 17. Lectures and assigned reading. Visits to the charitable institutions of the state by the class, and a detailed study of one institution by each student. Open to students who have had twelve hours in the 
department, including Course I7. (Alternate with Course 20.) Three hours, second semester. Professor M. R. Smith.

19. Criminology. The anthropology of the criminal, and the causes and conditions of crime. Lectures and assigned reading. Open to students who have had nine hours' work in the department. (Alternate with Course 17.) Three hours, first semester. Professor M. R. Smith.

30. Penology. Supplementary to Course I9. Methods of treating criminals; police, police stations and courts, county jails, state prisons, penitentiaries, and reformatories. Lectures, reading, visitation and study of penal institutions. Open to students who have had twelve hours in the department, including Course 19. (Alternate with Course 18.) Three hours, second semester. Professor M. R. Smith.

Social legislation.

\section{UNIVERSITY OF SOUTHERN CALIFORNIA.}

HISTORY AND ECONOMICS.

DR. Hoose.

Point of view of the courses in history: History is an account of ideas and institutions in movement, rather than an account of personalities and events. Ideas are thoughtful experience embodied in definitions or in documents; they change in form and content as experience varies under different conditions. Personalities are the agents who exploit ideas. Events are reactions among ideas and personalities. Institutions are ideas formulated in practice to serve the purposes of human being. Civilization is the sum total of ideas and institutions which exist at any given period of time upon any given portion of the earth $-i$. e., civilization is the evolution of ideas and institutions.

Point of view of the course in economics: The science of economics inquires into the sources and nature of wealth, and the relations which it sustains to individual, social, civil, and national well-being. This science investigates the principles and laws that are evolved by industrial, commercial, and social conditions. Political economy discusses the inventions and forms which human energies put forth to subordinate and utilize the forces of nature in order that they may see the needs, comforts, and luxuries of society.

VI. Seminary of political and social science. (Round table.) This course purposes to discuss special problems that measure civil, political, and sociological conditions - problems which arise out of movements and reactions among the elements of civilization. Elective for those college students who are prepared to enter upon the course. One hour, throughout the year.

\section{COLORADO- UNIVERSITY OF COLORADO. \\ DEPARTMENT OF PSYCHOLOGY AND EDUCATION. \\ Professor Dr. Charles E. Chadsey.}

16. Evolution of society. One semester, two hours. Application of theory of evolution to society. A study of the conditions that have made modern institutions possible. The causal idea in history. The family. Primitive law. Evolution of political institutions.

DEPARTMENT OF PHILOSOPHY.

Professor Dr. James M. Wilson.

7, 8. Applied ethics. One year, one hour.

Discussions and supplementary lectures. Two courses given in alternate year. 
I. Kidd, Social Evolution; Lecky, History of European Morals; Warner, American Charities.

II. Wright, Practical Sociology; Hoffmann, American Negro; Wine, Punishment and Reformation.

The problems of social morality, charities, criminology, good citizenship, socialism, etc.

\section{DEPARTMENT OF HISTORY AND POLITICAL SCIENCE.}

Outlines of sociology. One semester, three hours. Lectures, reading, discussion. The course aims to present a brief outline of sociological thought; a discussion of the elements of association underlying social relations and institutions; the results of race, group, and individual competition; the conditions of progress; some of the chief problems of sociology - population, degeneration, pauperism, dependent classes, crime, immigration, divorce, great cities, education. Elective, senior year.

\section{COLORADO COLLEGE.}

DEPARTMENT OF PHILOSOPHY.

President Slocum.

Ethical seminary, one hour. (a) Modern social and sociological problems.

Seminary in social ethics. The labor question, temperance, pauperism, and other social problems considered from the ethical standpoint. Second half-year, one hour.

\section{DEPARTMENT OF ECONOMICS.}

PROFESSOR URDAHL.

B. Charities and crime. The theory and history of charity and reformatory work. Students are encouraged to study the charitable and correctional institutions in the vicinity of their own homes. If possible, additional lectures by men who have devoted special attention to some phase of these subjects. (Warner, American Charities.)

D. Socialism.

E. Economic colonial policy.

\section{UNIVERSITY OF DENVER. \\ DEPARTMENT OF PSYCHOLOGY.}

B. Psychology in relation to sociology, ethics, and the sciences. This course treats instinct, impulse, pain and pleasure, and the social mind as factors in social and ethical development; also the biological foundation of psychology. Thirty-six hours.

\section{ILIFF SCHOOL OF THEOLOGY.}

(1900) Church polity and sociology. Forty-eight hours.

\section{CONNECTICUT- TRINITY COLLEGE. ECONOMICS. \\ Professor Ferguson and Mr. Watkins.}

Ec. 3 (VI). Elective for seniors in 1900-1901. Practical economic and social problems: immigration; legislative treatment of certain moral problems; relation between labor and capital; control of natural and capitalistic monopolies; crime and pauperism; discussion of criticisms of the present economic and social order. The work will be based upon Wright's Outline of Practical Sociology, but will include much supplementary reading. Reports upon reading and two written theses will be required. 
Ec. 3a(VI). Elective for seniors in 190I-2. Sociology: The purpose and scope of the study. The nature of society. The races of men. The Lamarckian and Weismann theories of heredity. Social effects of charity and modern sanitation. Progress by selection and by imitation. History of institutions. Some notable individual theories of social evolution. Four written theses will be required.

WESLEYAN UNIVERSITY.

ECONOMICS AND SOCIAL SCIENCE.

Professor Fisher.

V. The general labor problem. A course of lectures on the nature, causes, and justification of the present social discontent, and on such suggested remedies as moral elevation, charity, education, provident institutions, labor organizations, strikes, conciliation and arbitration, labor legislation, improved wage systems, profit-sharing, co-operation, nationalization of the land, socialism, communism, anarchism.

Course V is elective for those who have taken Course I. Courses IV and V are given in alternate years, Course IV being omitted the present year.

VI. Sociology. A discussion of the fundamental principles of social organization, and the conditions and forms of social progress.

Course VI is elective for those who take, or have taken, Course I.

[VII. Social science. An examination of certain concrete social problems of the present : pauperism and charity; the defective and criminal classes. The classroom work is supplemented by visits to several of the charitable, penal, and reformatory institutions in and about Middletown. Twice a week.]

Course VII is elective for those who take, or have taken, Course I. Courses VI and VII are given in alternate years, Course VII being omitted the present year.

*VIII. Economic seminary. Each member of the seminary takes for private individual investigation, under the direction of the instructor, some problem in economics, finance, statistics, or social science, and week by week reports in class on progress made and obstacles met. At the close of the year the work is brought together in a final report or thesis.

Course VIII is elective, with the permission of the instructor, for those who, having received first or second grade in Course I, take any three of the Courses III-VII.

YALE UNIVERSITY.

THE SOCIAL SCIENCES.

Professor SUMner.

2. The self-perpetuation of society (sec. 2 of systematic societology). A historical and ethnological study of the evolution of the marriage institution; mores, taboo, idealization. The family; its forms, parenthood, kinship, status of woman. Comparative legislation on domestic relations. Population. The history, law, and policy of population. Seventy-two hours.

The mental reactions (sec. 4 a of systematic societology). An ethnological study of the development of the mental processes and of the mental outfit of the human race in the earlier stages. Ghost-fear, daimonism, otherworldliness, knowledge and pseudo-knowledge, the aleatory element, world-philosophy, mores, codes, taboo, therapeutics, etc. Seventy-two hours.

4. The beginnings of the industrial organization. An ethnological study of the industrial organization from its earliest beginnings. Division of labor between the 
sexes, and the special functions of each ; regulation of industry; slavery; formation of capital; discoveries and inventions; domestication of animals and plants; money, etc. Seventy-two hours.

5. The science of society. An elementary course, with text-book lessons and examination in anthropology and ethnology, with the origin of civilization, and the development of institutions. In connection with this there will be a course of lectures on systematic sociology (societology). Topics are: the organization of society; the individual and the social; social forces; militarism and industrialism; property; family and the status of women; primitive notions in religion and philosophy; civil government; law and rights; slavery and classes; economic interests and their collisions ; conditions of welfare ; origin of moral standards ; reaction of reason on experience. These topics are treated exclusively in the light of historical anthropology and ethnology.

6. The science of society. A course based on Lippert's Kulturgeschichte. Seventy-two hours.

$$
\text { DR. NORTON. }
$$

6a. Statistical study of the evolution of man. Statistical methods for handling the data of the somatic evolution of man. Special references will be made to the problems under variation, heredity, panmixia, regression, selection, and prepotency, with some passing notice of the practical applications in life insurance. Concrete cases will be studied at every point to illustrate the general principles. The methods of Pierson and Yale, and to a less extent of Galton, will be discussed. Seventy-two hours.

Professor Farnam.

8. Social politics. A critical and historical study of legislation designed to better the conditions of the weaker members of society, considered in its relation to self-help and voluntary activity. Seventy-two hours.

9. The modern organization of labor. These lectures treat of the historical antecedents and the development during the nineteenth century of associations of the wage-receivers. They therefore include an account of the structure, aims, and methods of such societies in different countries, together with a discussion of their relations to socialism, the factory system, labor disputes, labor legislation, workingmen's insurance, provision for the unemployed, and other features of the industrial world. Forty-six hours.

\section{DR. W. B. BAILEY.}

23. Elementary statistics. The sources and reliability of statistical data are discussed and the methods of distinguishing true and false inferences are pointed out. Index numbers are studied, and the lectures treat of the statistics of population, crime, suicide, property, etc. The attempt is made to determine the laws which govern the group-actions of men. Seventy-two hours.

24. American social conditions. A critical study of the principal phenomena which are characteristic of American society. The course will deal with the problems connected with the negro, concentration of population in cities, with the attendant dangers, immigration, poor-relief, labor organizations, liquor question, etc. Seventytwo hours.

25. Labor systems. The various theories concerning the payment of labor, the conflicts between capital and labor, strikes, lock-outs, co-operation, compulsory insurance, and the various plans for the amelioration of the workingman. Each 
member of the class will make a special investigation of an assigned topic. Thirtysix hours.

26. The economic systems of classical antiquity. A critical study is made of the political and social institutions of Greece and Rome. The lectures treat of the income land expenditure of the state, the currency, credit instruments, poor-relief, slavery and tenure, commerce, trade regulations, marriage institutions, etc. Thirty-six hours.,

Mr. RoBINSON.

28. Municipal politics. A study of the organization of the modern municipality its practical workings and its problems; its relation to the state, to the individual, and to industrial activity. In connection with the general treatment of the subject a special study will be made of the organization, administration, and working of typical municipalities, both American and European. Seventy-two hours.

29. Industrial combinations. A study of the modern tendency toward the concentration of interests in trade, transportation, and industry; the forms of industrial organization; the relation of aggregated capital to investors, wage-earners, competitors, and consumers; the various plans for regulating and controlling capitalistic monopolies. Lectures, readings, and the preparation of theses on the development of characteristic combinations. Seventy-two hours.

29a. Industrial policy. A historical and critical study of the state in its relation to industrial activity. The experience of modern states in the regulation, control, and operation of industry, together with an investigation of the results of municipal ownership of public utilities. Seventy-two hours.

Dr. Blackman.

30. Social philosophy. The principal sociological writers are classified in "schools," and their points of view and methods are compared and contrasted; $(a)$ contractual (Rousseau); $(b)$ positivist (Comte); $(c)$ evolutionary (Herbert Spencer, Drummond); $(d)$ biological (Schäffle, Worms); $(e)$ psychological (Tarde, Le Bon, Simmel, Giddings, Baldwin, Izoulet); $(f)$ group-wise, observational statistical (Gumplowicz, Le Play, Quetelet); $(g)$ theocratic (Old Testament); (h) Christian. Thirtysix hours.

30a. Practical sociology. This course includes the following topics: the four fundamental and perduring social institutions - family, church, state, and property; the negro; the immigrant; the city; the wage and factory system; and the defective, dependentvivious, and criminal classes (charities and corrections). The lectures are supplemented, and book reviews by the students. A visit of two or three days to the charity and correctional institutions of New York, for which careful preparation is made in advance, and which furnishes topics and illustrations for subsequent discussions in the class-room, will probably be made, as heretofore. Seventy-two hours.

3ob. Anarchism, socialism, and communism. This course is a study of definitions, historical developments, principles, and programs. Books, pamphlets, manifestoes, and party platforms are read, as far as possible in the original language, and reported upon for the discussion before the class. Special attention will be paid to anarchism this year. Thirty-six hours.

30c. Social ideals in modern English poetry. Dowden's French Revolution and English Literature and Scudder's Social Ideals in English Letters will be read a text-books, and portions of Coleridge, Wordsworth, Shelley, Byron, Burns, Tennyson, Browning, Lowell, and Whitman will be read and discussed. Thirty-six hours. 
Assistant Professor Gregory and Dr. Kellor.

31. Environmental influence on man. First term (Dr. Gregory): the relation of man to nature; a study of topography, climate, distribution and character of fauna, flora, building material, etc., as factors which influence man's physical development and manner of life. Second term (Dr. Kellor): social environment, including the interrelation of primitive and early societies, and of societies unequally advanced in civilization. Especial attention will be given to the contact of civilized with uncivilized races consequent to national expansion and colonization. Seventy-two hours.

33. Colonization (economic and social). The economic and social questions of colonization. A preliminary sketch of ancient and mediæval expansion and colonization, followed by a close study of the experiences of the various modern colonizing states. Investigation based on German and French sources is required, and ability to read Spanish or Dutch will be of advantage. Seventy-two hours.

YALE DIVINITY SCHOOL.

DEPARTMENT OF CHRISTIAN SOCIOLOGY.

Dr. Bailey.

Practical sociology. A critical study of the principal social phenomena that are characteristic of American society. The problems connected with the negro, the concentration of population in cities, with the attendant dangers, immigration, organizations for charity and the relief of the poor, the liquor question, and kindred themes will be presented in lectures. Considerable attention will be given to the institutions for the punishment of crime and the reformation of criminals. Wright's Practical Sociology and additional books of reference. Seventy-two hours.

\section{ALL CLASSES.}

"The Lyman Beecher Course for I901," by Rev. Dr. Gladden, will discuss special problems connected with the relation of the pulpit to present social conditions.

Further needs of students in this department are met by the courses of the Graduate School.

PRACTICAL WORK.

A number of general scholarships, averaging $\$$ I00 a year, are given to students engaged in practical religious and social work in the city. The supervision of this work is in charge of the director of religious work, a recent graduate employed solely for this purpose.

New Haven, with its population of 120,000 , offers a large and varied clinical field. It contains seventeen Congregational churches and strong churches of all denominations. The mission field includes the well-organized city missions, Wellcome Hall Mission, with its institutional features; Lowell House Settlement, in the midst of a large foreign population; the New Haven Hospital, where six students are used as chaplains; the jail, where work is done for discharged men in connection with the Calvary Industrial Home; the almshouse, clubs for street boys and workingmen, and the large city Y. M. C. A. This system affords excellent opportunity for actual experience in dealing with social problems, and is supplemented by a visit of two or three days to the charitable and correctional institutions of New York under Dr. Bailey's direction.

YALE LAW SCHOOL.

Group I I/4. The organization and working of human society.

I $1 / 4$. Sociology: the self-perpetuation of society; evolution of domestic relations. Professor Sumner. 
2. Systematic sociology. Professor Sumner.

3. Physical geography in its relation to history. Professor Brewer.

4. Mediæval institutions. Professor G. B. Adams.

5. Social politics. Professor Farnam.

6. Commercial policy. Professor Emery.

DISTRICT OF COLUMBIA-

THE CATHOLIC UNIVERSITY OF AMERICA - SCHOOL OF THE SOCIAL SCIENCES.

In the university the departments of sociology, economics, and politics have been grouped into the School of Social Sciences, the better to enable the candidates for the doctorate to grasp the general principles underlying all social phenomena, and to form thereby a juster appreciation of the laws of the particular science to which he devotes himself. This end is obtained by such an arrangement of the courses as will enable the student to make the best possible co-ordination of the sciences taught in this school with each other and with the allied science of law as taught in the School of Law.

This grouping renders it easier to make such a co-ordination of courses as will offer the greatest advantages to students taking work in the other schools of the university, and who desire, at the same time, to secure a good grasp of the general principles of the social sciences.

\section{DEPARTMENT OF SOCIOLOGY.}

Rev. Dr. William J. Kerby.

At present the work in sociology is largely introductory. While the science is in the formative stage, and is the occasion of much controversy, it seems best to give to the student clear fundamental ideas and exact preparatory knowledge. It is hoped that this method will develop powers of accurate observation and classification, and that it will generate a correct sociological sense. Sociological theory is studied historically rather than critically. The lectures and research work are conducted in a way to reach questions of social organization and life, social history and social problems. To preserve the useful character of the work, principles will not be studied without careful and detailed application to social conditions, normal and abnormal; and to preserve the scientific character of the courses, no sociological research, no study of social problems, will be undertaken, without the constant guidance of the principles involved.

\section{COURSES OF INSTRUCTION.}

I. Elements of sociology. The purpose of this course is to acquaint the student thoroughly with the terminology of the science, its fundamental concepts, the nature of society, of social phenomena, of social laws, and of social institutions, classes, etc. Two hours.

II. The social sciences. (a) Analytical study of their problems and relations to sociology. (b) Review of attempts to construct a complete theory of sociology. Two hours per week till completed.

III. The sociological aspects of mediæval guilds. Two hours per week after the completion of Course II.

IV. Seminar. Hints on methods of sociological study and observation ; papers by students on selected subjects; current periodical literature and current events reviewed; exercise in bibliography. Two hours. 


\title{
DEPARTMENT OF ECONOMICS.
}

\author{
Dr. Carroll D, Wright and Dr, Charles P. Neill.
}

V. Lectures on special topics in social economics. This course, conducted by Hon. Carroll D. Wright, United States Commissioner of Labor, treats of the use and method of statistics in the study of industrial and social questions, and discusses problems of present importance in the field of social economics. One hour. Second half-year.

The resignation of Professor Carroll D. Wright, on account of the present financial difficulties of the university, has just been announced in the press.

\section{COLUMBIAN UNIVERSITY - THE CORCORAN SCIENTIFIC SCHOOL.}

POLITICS AND ECONOMICS.

Professor Craven, Head of Department; Dr. Wright, Lecturer on Statistics; Mr. MCNABB, InSTRUCTOR in Business LAw.

VI. Comparative statistics. A numerical study of social relations, with particular regard to the population, industries, and commerce of the United States and other leading nations. Two hours, 1901-1902.

\section{SOCIOLOGY.}

XI. The principles of sociology. Two hours, I900-190I.

XII. A study of individualism, socialism, and of the practical social problems of state and municipal administration in respect to sanitation, charities, crime, etc. Two hours, I901-1902.

\section{COLUMBIAN UNIVERSITY - THE SCHOOL OF GRADUATE STUDIES.}

\section{ECONOMICS.}

\section{Associate Professor West.}

III. Municipal economy. A study of municipal functions in various countries and of the corresponding forms of municipal government. The actual experiences of cities in dealing with the problems growing out of the concentration of population will be compared, with a view to determining how far and in what directions the modern tendency toward the extension of municipal activities is advantageous.

IV. Social therapeutics. A study of voluntary agencies for promoting social welfare.

\section{GEORGETOWN UNIVERSITY.}

\section{PHILOSOPHY.}

Course 3. Special ethics. Duties and rights. Individual law. Revelation. Public worship. Self-culture and station in life. Suicide. Private ownership. Dueling. Lying. Social law. Domestic society. Divorce. Celibacy. Education. Civil society. Authority.

Politics. Forms of government. Essential functions: legislative, judiciary, executive. Armed force. Civil administration. Penal code. Church and state. Ecclesiastical society. International law. Intervention. War and peace.

Course 4. Distribution. The social problem. Socialist solution. Rights of property. Classes of sharers : autonomous producer, master, wage-earner, man living on his income, the indigent. 
I. Introduction to the study of society. Small and Vincent's Introduction to the Study of Society forms the basis of instruction, and the course is designed to afford a synthetic view of social phenomena. It is a fitting introduction to the special social sciences.

II. Social elements - lecture course. The attempt is to direct attention to the phenomena of human associations, to show how to interpret social and economic tendencies and movements, to stimulate interest in methods of social betterment approved by experience, and to disclose the principles of social progress.

III. The history of sociology. This consists of a general survey of sociological thought from Comte to the present time by means of lectures, and reports by the students.

\section{ROLLINS COLLEGE.}

ECONOMICS AND LAW.

Course V. Sociology. An introductory course, dealing with the history of sociology as a science. Some of the subjects treated are anthropology, ethnology, the philosophy of social life, applied sociology, statistics, and present social problems. Second semester, three times a week. Required of all candidates for the degree.

\section{GEORGIA-}

ATLANTA UNIVERSITY.

W. E. Burghart DuBors, Ph.D.

Social reforms. Three terms of the senior year are given to sociology; the first term to a general study of principles, the second term to a general survey of social conditions, and a third term to a study of the social and economic condition of the American negro, and to methods of reform. Mayo-Smith's Statistics and Sociology is the text-book in use, and special library and thesis work is required.

In addition to this, graduate study of the social problems in the South by the most approved scientific methods is carried on by the Atlanta Conference, composed of graduates of Atlanta, Fisk, and other institutions. The aim is to make Atlanta University the center of an intelligent and thoroughgoing study of the negro problems. Five reports of the conference have been published, and a sixth is in preparation.

HAWAII-

OAHU COLLEGE.

DEPARTMENT OF ECONOMICS.

II. Principles of sociology; sociological problems. Sixty hours.

\section{ILLINOIS- \\ ILLINOIS WESLEYAN UNIVERSITY.}

GROUP H. ECONOMICS AND SOCIOLOGY.

DR. LYoN.

General history, civics, logic. Economics. Spring term.

Course I. Economics. Fall term.

General history, civics, logic. Sociology. Spring term.

Course 1, 3. Sociology. Fall term.

Courses I, 3, 4. Sociology, seminary. Winter term.

$$
\text { II. SocroLogy. }
$$

The purpose in sociology is to trace the evolution of society from its primitive forms to its present state of complexity, to note the reciprocal adjustment of life and 
environment, to see how forces both subjective and objective have operated to bring about a normal state of society, and to examine the forces which are now tending to change its structure.

An elementary study of social principles and phenomena (I). Origin and scope of sociology. Origin and nature of social structures. Social functions. Mental and physical basis of society. Constant observation and classification of local social phenomena. By this method and historical data social theory is tested.

The principles of sociology (2). Relation of sociology to correlated sciences. An examination of the nature and application of all the principles constituting society. These principles are traced in the evolution, not only of the social mind, but also of the objective structures of society. Theses on various phases of the subject.

Seminary (3). A study of such sociological problems as organized charity, socialism, communism, crime, urban life and social selection, negro, immigrant, sociological study of the family, social teaching and the influence of Christianity.

BLACKBURN UNIVERSITY.

POLITICAL SCIENCE DEPARTMENT.

WaLter H. Bradley, A.M.

SOCIOLOGY - GENERAL.

Discussion of the phenomena of society and present social problems. Thirty-six hours.

\section{CARTHAGE COLLEGE.}

DEPARTMENT OF HISTORY, ECONOMICS, AND SOCIAL SCIENCE.

Sociology. Wright's Practical Sociology. Theses and supplementary reading. Three months, three hours.

\section{UNIVERSITY OF ILLINOIS. \\ DEPARTMENT OF ECONOMICS.}

I2. The labor problem. This course is a study of the labor movement and its social significance. The conditions of workingmen, their legal and economic relations to their employers, wages, strikes, arbitration, labor organizations, and similar topics are studied, and serve to show the general character of the course. Readings, lectures, and quizzes. Professor Kinley.

15. Problems of pauperism and crime. This course begins with the history of poor-relief in Europe and the United States. As full a discussion of the various methods of reform and prevention is given as the time will permit. Assistant Professor Hammond.

I7. Sociology. This course comprises an elementary presentation of social principles and phenomena, and a brief discussion of some of the recent theories advanced to explain the growth and structure of society. Assistant Professor Hammond.

\section{UNIVERSITY OF CHICAGO.}

DEPARTMENT OF SOCIOLOGY AND ANTHROPOLOGY.

GENERAL SOCIOLOGY.

Prevalent misconceptions make it necessary to advise students that sociology is neither the sum of modern experiments in beneficence, nor the formulation of benevolent sentiments, nor a dogmatic short-cut to the solution of problems which baffle political and economic science. 


\section{II6 THE AMERICAN JOURNAL OF SOCIOLOGY}

Sociology is, first, a philosophy, that is, a correlation of the methods and results of the special social sciences; second, an application of social philosophy to concrete problems. Social philosophy is invalid, unless it is chiefly constructed from data authenticated by the antecedent sciences. Social programs, whether for society in general or for minor social endeavor, are without scientific credentials unless they are indorsed by social philosophy thus derived.

The Department of Sociology has, accordingly, the following special aims : (I) to furnish such expositions of social relations and theories as will serve the general purposes of educated citizens ; (2) to train teachers for similar work of general exposition in colleges ; (3) to furnish professional equipment for other vocations devoted to social service, including the offices of public instruction through pulpit, platform, press, and the work of organizing enterprises for social improvement ; (4) to unite in the seminars companies of advanced students capable of the most comprehensive thought upon social philosophy, and to enlist them in co-operation for first-rate contribution to social doctrine. To this end fellowships are assigned to specially competent students of sociology.

FACILITIES FOR STUDY.

The facilities for sociological study at the University of Chicago are unsurpassed. The differentiation of departments devoted to social phenomena and the division of labor within the departments is nowhere more distinct and minute. The city of Chicago is one of the most complete social laboratories in the world. While the elements of sociology may be studied in smaller communities, and while it may be an advantage to beginners in the method of positive sociology to deal at first with more simple social combinations, the most serious problems of modern society are presented by the great cities, and must be studied as they are encountered in concrete form in large populations. No city in the world presents a wider variety of typical social problems than Chicago.

The instructors in the Department of Sociology aim to use the scientific material thus afforded both for didactic and constructive purposes. They find a large proportion of their opportunities for research in co-operation with the public-spirited men and women of the city. They are active members of many organizations of citizens for the purpose of investigating and shaping the life of Chicago. Graduate students in the department are taught to work among social facts, and to test and form theory by experience.

Thus the organized charities of the city afford graduate students of the university both employment and training. The church enterprises of the city enlist students in a similar manner. Several students of sociology have been residents and workers at Hull House. A social settlement upon the plan of Hull House has been founded and maintained by students and instructors in the university. Social organizations of every description, from trades unions to the Civic Federation, afford illustrations of every type of modern social experiment and opportunity for the largest variety of observation and experience. Representatives of all these phases of social effort cordially co-operate with the Department of Sociology in making these social endeavors tributary to the training of sociological students. It is the purpose of this department to appropriate to the utmost every advantage afforded by the vast social laboratory within which the university is located. This purpose will be especially prominent in connection with the work of the social settlements. While the primary aim of these enterprises is improvement of the district in which they are undertaken, 
the settlements are social observing stations where invaluable supplementary experience should be sought by students, and where material is to be gathered by mature investigators. In so far as the work of the settlements is guided by the university, it will not stop with exhibitions of altruistic sentiments. It will attempt to test general hypotheses and to establish scientific conclusions by use of the evidence which actual experiment affords.

On the other hand, the breadth of the university itself makes empirical and provincial study of sociology impossible. The differentiation of departments does not imply isolation of thought. Scientific work in sociology largely depends upon logically antecedent sciences, not only for material, but for method. This dependence is recognized in the requirements specified below. More than this, it frequently occurs that the kind of research which is decisive in a particular sociological investigation is the more appropriate work of another department. Graduate work in sociology accordingly involves frequent resort to cognate departments.

SPECIAL REGULATIONS.

The subjects in the Department of Sociology and Anthropology fall into the following groups: $A$, social philosophy; $C$, social psychology; $D$, social technology.

Candidates for the higher degrees, if otherwise qualified, may choose either of these groups as principal or secondary subject. The minimum amount of work accepted for the degree of A.M. is six majors, or for the secondary subject leading to the degree of Ph.D., nine majors.

If either of the above groups be chosen as the principal subject for the degree of $\mathrm{Ph} . \mathrm{D}$., the equivalent of eighteen majors within or under the direction of the Department of Sociology and Anthropology will be required.

The following table exhibits correlations of courses to be included in the work on which candidates for the higher degrees will be examined. Certain substitutions of equivalent work may be made by previous arrangement with the department.

\begin{tabular}{|c|c|c|c|}
\hline & Group $A$. & Group $C$. & Group $D$. \\
\hline For A.M. $\ldots \ldots \ldots \ldots \ldots \ldots \ldots \ldots \ldots \ldots \ldots \ldots \ldots$ & \begin{tabular}{|cc}
\multicolumn{3}{c}{ Course 72} \\
66 & 26 \\
6 & 73 \\
6 & 53
\end{tabular} & $\begin{array}{cr}\text { Course } & 72 \\
6 & 26 \\
“ 6 & 30 \\
“ & 53\end{array}$ & $\begin{array}{cc}\text { Course } & 72 \\
4 & 53 \\
\text { ، } & 56 \\
\text { “ } & 26\end{array}$ \\
\hline For Ph.D. (secondary)...... & 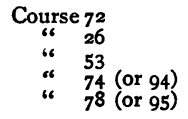 & $\begin{array}{l}\text { Course } 72 \\
\text { “ } 26 \\
\text { “6 } 53 \text { (or 94) } \\
\text { “ } \quad 74 \text { (or 27) }\end{array}$ & $\begin{array}{cl}\text { Course } 72 \\
6 & 26 \\
\dddot{6} & 53 \\
\text { "6 } & 74 \text { (or 94) } \\
6 & 56\end{array}$ \\
\hline For $\mathrm{Ph} . \mathrm{D}$. (primary) $\ldots \ldots \ldots \ldots \ldots \ldots$ & 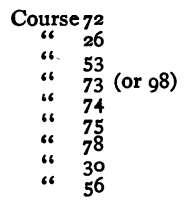 & 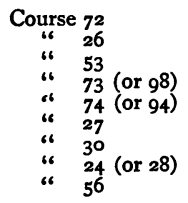 & 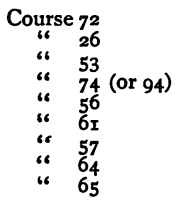 \\
\hline
\end{tabular}

24. Art and the artist class. The relation of æsthetic activities to other forms of race activity and consciousness. Animal play and rudimentary expressions of art in animal 
societies. Mutilation, artificial deformation, stimulants, ornament, dress, tattooing, the dance, music, poetry, painting, sculpture, technology, ceremonial, humor, and play among the natural races. The relation of art to work. Art and gaming in Chicago. From the standpoint of origins. For graduate students. Major. Associate Professor Thomas.

26. Social origins. Association and culture in early times and in tribal life. Early food conditions, migrations, and race-crossings. Origins and relations of invention, trade, warfare, art, marriage, class distinctions, the professions, legal, political, and ecclesiastical institutions. Ethnological reading. An introductory. For Senior College and graduate students. Major. Associate Professor Thomas.

27. Development of mind in the race. Formation of habit in the tribal stage. Relation of the psychic life of the group to the group activities. Instruction and discipline of children by the parents and by the group. Educational meaning of initiation, secret societies, and tapu. Animistic beliefs and practices, and the influence of analogy, suggestion, and hypnotism in the formation of mind. Language and number. Imitation, invention, and genius. Comparison of the mental traits of different races, epochs, and social classes, and an estimate of the nature of the psychic interval between the natural and the culture races. For graduate students. Major. Associate Professor Thomas.

28. Sex in social organization. The influence of the fact of sex in the development of forms of association and of social activity and structure. Based principally on data from the natural races, and from the population of the city of Chicago, with a preliminary consideration of sex in the lower life-forms. For graduate students. Major. Associate Professor Thomas.

30. Primitive social control. A study of primitive juridical and political systems and of social conventions. Family, clan, tribal, and military organization, totemism, tribal and property marks, tapu, personal property and property in land, periodical tribal assemblies and ceremonies, secret societies, medicine men and priests, caste, blood vengeance, salutations, gifts, tribute, oaths, and forms of offense and punishment, among typical tribes of Australia and Oceanica, Africa, Asia, and America. Major. Associate Professor Thomas.

3I. Race development of mind. Research course. Major. Associate Professor Thomas.

51. Contemporary society in the United States. A concrete study of natural conditions, the population and its distribution, institutions, economics, political, educational, and ecclesiastical, together with an examination of conventional ideas as to national characteristics. The course is designed to afford a general survey, and to correlate geography with social and economic history and political science. Major. Associate Professor Vincent.

52. American cities. A study of the location, growth, population groupings, arrangements, architecture, and typical institutions of American cities. The aim of the course is to put the problems of the modern city into their proper relations, to exhibit urban life as a whole. Visits to certain city institutions constitute a part of the course. Major. Associate Professor Vincent.

53. The family. The development of the domestic institutions in lower and higher civilizations; social ethics of the family; legal, industrial, educational, and religious problems of the family. Major. Professor Henderson.

56. The group of industrials. The labor movement from the viewpoint of sociology. 
The influence of habitat, race, inheritance, migration, division of labor, towns, institutions, and conventions on the differentiation and opportunities of the so-called operative class, the actual condition of this group, and their participation in the goods of civilization; the essentials of a truly human existence ; the modes by which improved ideals of welfare originate and are diffused; the social system of economic, political, and cultural organization through which the group must enjoy the social inheritance; description, criticism, program of amelioration. Major. Professor Henderson.

57. Rural communities. Conditions of social existence in the country; organization for improvement. Minor. Professor Henderson.

58, 59, 60. Seminar: methods of social technology. Discussions, reports, and thesis work on contemporary movements for social betterment, chiefly on the basis of studies of Chicago life. Three majors. Professor Henderson.

6r. Urban communities. Method of analytic study of social organization; comparisons of ancient and modern cities; the system of community bonds and interests ; functions of political, economic, and cultural organizations as determined by social interests; the modes of quickening higher wants and the co-operation of public and private agencies in their satisfaction. Major. Professor Henderson.

62. Moral and culture statistics, methods and results.

63. Social institutions of organized Christianity. Methods by which the church and its societies minister to the welfare of communities. Major. Professor Henderson.

64. Contemporary charities. Studies of the nature and origin of depressed and defective classes; principles and methods of relief; organization of benevolence. Major. Professor Henderson.

65. Social treatment of crime. Causes of crime; principles of criminal anthropology; prison systems; legal factors, juvenile offenders ; preventive methods. For graduate students. Minor. Professor Henderson.

67. The structure of English society. A study of the economic, physiological, social, æsthetic, intellectual, and ethical elements in a typical society. Major. Associate Professor Zueblin.

68. Philanthropy in its historical development. Major. Professor Henderson.

69. The elements and structure of society. A study of the economic, physiological, social, æsthetic, intellectual, and moral elements in American society. The interrelation of the individual and the group. The problem of social progress in a democratic society. Major. Associate Professor Zueblin.

70. Municipal sociology. An examination of the means of satisfying communal wants through public activity, with special reference to British and American cities. Lectures and reports. Visits to municipal institutions. Major. Associate Professor Zueblin.

7I. An introduction to the study of society. This course is designed to serve as an introduction to the special social sciences of economics, political sciences, etc. For Junior and Senior College students. Major. Professor Small.

72. An introduction to sociology. Designed to orient the student in the current theories of social interpretation by tracing briefly their development. A rapid historical survey, including Machiavelli, Vico, Montesquieu, Turgot, Comte, Spencer, Lilienfeld, Schäffle, et al. The organic concept of society will be presented, illustrated, and criticised, and the current psychological theories of imitation, invention, opposition, will be briefly outlined. For Senior College and graduate students. Major. Associate Professor Vincent. 
73. Public opinion. This course will include $(a)$ an analysis of the concept of the public or general mind, $(b)$ a study of the mechanism of public opinion, $(c)$ its growth and guidance, $(d)$ the social psychology of fashion, $(e)$ mob or crowd psychology, and $(f)$ the function of public opinion in a democracy. For graduate students primarily. Senior College students admitted by permission of the instructor. Major. Associate Professor Vincent.

74. The methodology of the social problem. Based upon Course 78. A definition of the task of sociology, and of its relations to the specific social sciences. Professor Small.

74A. A synopsis of sociological theory. Designed to furnish a conspectus of general sociology. Minor. Professor Small.

75. The ethics of sociology. Major. Professor Small.

It is recommended that Professor Dewey's courses, the logic, the psychology, and the sociology of ethics, be taken either before or with Course 75 .

76. The elements of social dynamics. A study of the permanent forces that shape human society. Courses $71,72,73,26$, and 74 are presupposed. Major. Professor Small.

77. The social philosophy of the English people in the Victorian era. Major. Associate Professor Zueblin.

78. The development of sociological method. From Comte to the present time. The object of this course is to discover the successive statements of the sociological problem, with the premises, methods, and results in the most influential writings, as an introduction to the necessary formulation of the sociological problem. Professor Small.

79. The sociological conception of society. For Senior College and graduate students. Major. Professor Small.

80. The sociological conception of the state and of government. (See Course 96.) For Senior College and graduate students. Major. Professor Small.

82, 83, 84. Seminar. Problems of social teleology. Three majors. Professor Small.

85, 86, 87. Seminar. Problems of social dynamics. In this course the facts of social psychology are studied with reference to the possibilities of telic progress. Three majors. Professor Small.

$88,89,90$. Seminar. Problems in methodology and classification. Three majors. Professor Small.

91. American experience with state control of social action. Major.

94. The premises of general sociology. Major. Professor Small.

95. An outline of general sociology. Major. Professor Small.

96. The sociological conception of the problems of modern democracy. Continues, but does not necessarily presuppose Courses 79 and 80. Major. Professor Small.

96A. Democracy and the social movement in the nineteenth century. Minor. Professor Small.

98. Education as a social function. Major. Associate Professor Vincent.

THE SOCHOLOGY CLUB.

The members of the Sociology Club are the instructors and graduate students in the Department of Sociology and Anthropology. By a vote of two-thirds of the mem- 
bers of the club other persons, whether connected with the university or not, may be admitted to membership.

The purposes of the club are: " $(a)$ co-operation in the study of current sociological literature, especially the periodicals of Europe and America; $(b)$ exchange of information about books upon sociology; $(c)$ formation of acquaintance with workers in the various kinds of social endeavor, whether theoretical or practical ; $(d)$ mutual assistance, through criticism of studies upon sociological subjects presented by the members; $(e)$ support, whenever practicable, of social efforts organized either by members of the university or by citizens of Chicago." Meetings are held every fortnight.

\section{DEPARTMENT OF PHILOSOPHY.}

42, 43. Sociology of ethics. This course will approach the problems of ethics from the standpoint of social organization. In the autumn the ethical problems relating to the various institutions of society will be discussed; in the winter the ethical problems relating to the connection of the individual and society. For graduate students. Two majors. Professor Dewey.

44. The psychology of ethics. This course will include particularly the ethics of self-control and self-realization, and the significance of psychological analysis for ethical theory. For graduate students. Major. Professor Dewey.

45, 46. The evolution of morality. This course will give a general review of the typical facts in the growth of moral customs and ideals. In the autumn quarter primitive human morality will be discussed, considering three or four types of tribal life, and the ethical development of institutions and the individual in these types. The method pursued is that of social psychology. In the winter quarter the Hebrew, Greek, and Roman civilizations will be discussed as regards their contributions to present moral practices and ideas. For graduate students. Two majors. Professor Dewey.

19. Contemporary social psychology. The development of social psychology from individual psychology will be traced, and its justification and methods discussed. Major. Associate Professor Mead.

\section{DEPARTMENT OF POLITICAL ECONOMY.}

3. Economic and social history. The object of this course is to trace for students of history and political science, as well as of economics, the development of the economic organization of society down to the time of the so-called industrial revolution in the latter part of the eighteenth century. Preparation is thus afforded for the detailed examination of special phases of the more recent economic evolution provided for in the courses upon railways, banking, agriculture, industrial combinations, etc. Major. Dr. Mitchell.

14. Economics of workingmen. The purpose is to treat of efforts made to improve the condition of workingmen, and the effects of co-operation, profit-sharing, building associations, manual training, trades unions, and the like. Major. Assistant Professor Veblen.

The University of Chicago.

Frank L. Tolman.

\section{[To be continued.]}

